\title{
Legal Protection of Women Forced to Married In Islamic Law and Human Rights Perspective
}

\author{
${ }^{1}$ Anwar Hafidzi, ${ }^{2}$ Rina Septiani \\ Universitas Islam Negeri Antasari, Universitas Nahdlatul Ulama Indonesia \\ anwar.hafidzi@uin-antasari.ac.id
}

\begin{abstract}
ABSTRAK
Penelitian ini bertujuan untuk mengetahui perlindungan hukum terhadap perempuan yang di paksa kawin menurut hukum Islam dan Hak Asasi Manusia. Metode yang digunakan dalam penelitian ini bersifat deskriptif kualitatif dengan pendekatan hukum normative yaitu dengan menganalisi permasalahan melalui data-data dari literatur hukum. Hasil dari penelitian menemukan bahwa Undang-Undang pekawinan di Indonesia tidak mengenal adanya hak ijbar, sebaliknya dalam undang-undang tersebut mengharuskan adanya persetujuan kedua belah pihak untuk melangsungkan pernikahan dengan keridhaan tanpa paksaan. Reinterpretasi hak ijbar dianggap objektif dan sesuai Hak Asasi Manusia dikarenakan konsep ini didasari atas bentuk perlindungan dan tanggung jawab dalam memilih pasangan hidupnya.
\end{abstract}

Kata Kunci :kawin paksa, hak mujbir, HAM

\section{ABSTRACT}

This study aims to determine the legal protection of women who are forced to marry according to Islamic law and human rights. The method used in this research is descriptive qualitative with a normative legal approach, namely by analyzing the problem through data from the legal literature. The results of the research found that the marriage law in Indonesia does not recognize the right to consent, on the contrary, the law requires the consent of both parties to enter into a marriage with pleasure without coercion. The reinterpretation of Ijbar 's right is considered impartial and compatible with human rights since it is based on a type of security and transparency when choosing a life partner.

Keywords: forced marriage, mujbir rights, human rights

\section{INTRODUCTION}

Everyone has the right to choose his/her life partner on his behalf without coercion by others (Hafidzi \& Hayatunnisa, 2018). Islamic teachings never teach coercive behavior (ikraah) and discriminate against others. Even in Islam, it considers the values of equality (al-musawah) and freedom (al-hurriyah) in solving problematics (Ab Rashid et al., 2018, p. 3; Musa, 2017). Everyone has the right to take legal actions as long as he can be responsible, and someone's freedom to claim that right can be limited by the rights of others. To have a belief, it must be free from coercion. The religious teachings contained in both the Qur'an and Hadith always contain transcendent and permanent elements and can adjust to any place and time. Even so, some humans only interpret these verses textually, these verses should also be interpreted contextually when conveyed to others (Muslih, 2016, p. 257). 
The issue of marriage, Islam has widely regulated, from how to find and select the criteria for a life partner to how to treat it when officially becoming a life partner. Islam has its guidance, so does Islam teaches how to make a beautiful household with a life partner that should be liked and desired. Marriage is an agreement/bond between a man and a woman to pursue domestic life and obey Allah's commandments and its implementation is worship. According to Bell and Harsin (2018) Marriage should be based on the pleasure of the prospective husband and wife. But what if the marriage occurs not based on love, but because of compulsion, both from one party and both parties (AlQodsi, Bidin, Al-Shafi, \& Muda, 2020, p. 408; Bell \& Harsin, 2018).

The right to the consent of a guardian can lead to different types of violence against women distracting from the intent of marriage itself. This means (Izzati, 2011, p. 253)that the rights of wali are incoherent because, instead of leading women to household misery, the role and place of the wali mujbir is not happiness as the principal reason. Such as from some literature the Islamic jurisprudence book Fiqh Islam wa adillatuh which discusses the authority and rights of the Mujbir Guardian by Wahbah Zuhaili. Therefore the approach of faith is more necessary in order for parents to have happiness in the future, in the right of marriage for forced marriage. Coercion (ikraah) according to language means telling other people to do something that they don't want naturally (Gill \& Hamed, 2016, p. 540). Islamic law requires marriage based on mutual love to create a Sakinah, Mawaddah, Warrahmah family, and positive law also regulates that a human being has legal protection over himself, namely the existence of human rights. Then in Islam, the concept of known ijbari (forced marriage) is, so the question arises how is the legal situation for women who are forced to marry? Does Indonesia have legal protection against women who are forced to marry?

\section{METHOD}

This writing was conducted based on the results of research on several library materials in the form of statutory regulations and various pieces of literature, documents, papers, theses, and other scientific works related to forced marriage. In this study, the authors used a normative juridical legal research method that is descriptive-analytical. This type of normative research, namely collecting data and legal materials from various kinds of references.

This type of research will examine in depth the principles of law, statutory regulations, jurisprudence, and the opinion of legal experts and view the law comprehensively, meaning that law is not only a set of normative rules or what constitutes legal text (law in book) but also see how the law works (law in action). Secondary sources are also some literature on fiqh islam wa adillatuh, Compilation of Islamic Law (red: KHI), Marriage Law and Human Rights Law in Indonesia. 


\section{DISCUSSION AND RESULTS}

\section{Definition of Marriage}

Based on article 2 chapter II of the Book I Compilation of Islamic Law (HKI), it is stated in its definition: "Marriage according to Islamic law is a marriage that is a very strong contract or mistaqon gholidhan to obey Allah's commands and carry it out is worship". From the background of this definition, it is clear that in a marriage there is a very strong bond between husband and wife, which in turn creates a sense of affection and love (Hedi, Anshori, \& Harun, 2017, p. 264). Marriage should be done to unite two people to have a family. Since agreeing to the contract, both parties have had the obligations and rights as husband and wife. The purpose of marriage is none other than to create a safe, peaceful home life, a relationship that loves and cherishes each other (Hori \& Cipta, 2019, p. 18).

Adult women, according to the view of the majority of the ulama ', are considered to have their ability to carry out legal actions related to financial transactions, such as trade, employment, and others. This view is consistent with the provisions of Law Number 39, 1999 concerning Human Rights. Therefore, women have the right to do actions related to matters of privacy, including determining their future husband. Marriage problems are closely related to social change (Sanford, 2017, pp. 46). Social change occurs more quickly and easily if a community frequently makes contact with other communities and already has a more advanced education system, a system of social strata that is open and is accompanied by a civilian population, these are the factors that can facilitate social change in society (Hafidzi, 2019, p. 52; Mohd \& Kadir, 2020).

In today's context, marriage is often interpreted as a demand for social obligations rather than a desire for oneself. In general, it can be understood in traditional society, that marriage is defined as a social necessity which is the custom/tradition of the community (Faradila, 2019). Whereas in modern society, marriage is interpreted as a condition for making choices and is considered a social contract. Thus, the practice of forced marriage which is still ongoing today is due to the stigma of society regarding the right of consent which has the power to a father or grandfather to forcefully marry his child because it is considered to have more knowledge and authority over the child, so that forced marriage can be justified by part of society (Habibi, 2017).

\section{Definition of wali (marriage guardian)}

In language, the word wali is derived from the expression wala 'asy-shay' wa ala 'alaihi wilayatan wa wilayatan which means "to master" in addition to these words there are also those that mean "to help and help him". Meanwhile, the word alwalayatan is interpreted as helping, while al wilayat is interpreted as "power and 
strength"(Mahbub, 2016). From this meaning, it is understood that a guardian for a woman is the one who has the right or power to carry out her marriage contract and she does not allow it to be disturbed by others. Meanwhile, according to the term guardianship (area) is the power in the Shari'a which is owned by a person who has the right to carry out tasharruf (activities) related to other people's circumstances or affairs to help him.

Fuqaha in marriage classify guardians into several types (Lahaji \& Ibrahim, 2019, pp. 20-22): First, in terms of the nature of guardianship, it is divided into lineage guardians, namely guardians who still have blood/family relations with the woman and the judge's guardian. Second, in terms of existence it is divided into wali aqrab (near) and wali ab'ad (far). Third, the guardian is divided into wali mujbir and wali ghairu mujbir.

\section{Kinds of guardian}

Guardianship in marriage is divided into four types, namely: descent guardian, judge guardian, muhakkam guardian, and guardian maula (Muttaqin $\mathcal{E}$ Fadhilah, 2020).

a. Wali Nasab (descent)

Is a person who has the right to make the marriage contract of the prospective bride because of blood relations (descent). the scholars divides wali nasab into two parts, namely (Syaifullah, 2016):

First, close guardian or wali aqrab, namely father and if there is no father can be replaced by grandfather. Both have absolute power over girls who are still under their control, that is, they can marry them off without the child's consent. This guardian is also called the wali mujbir.

Second, distant guardians or wali ab'ad are guardians in the line of relatives apart from father and grandfather.

b. Guardian Judge

The guardian of the judge is the guardian of marriage appointed by the Minister of Religion or an official appointed by him, who is given the right and authority to act as the guardian of marriage, however, the authority of the guardian of that line can be transferred to the guardian of the judge if (Mahbub, 2016):

1. There is a dispute in among those saints.

2. If the wali nasab is absent or present but unable to present him, or where his / her place of residence is unknown or unseen/missing or reluctant (adlal). Wali adlal is a guardian who is reluctant to marry a woman who has grown up to a man of her choice.

The Islamic Shari'ah stipulates the existence of a judge's guardian to present difficulties in carrying out a marriage, while marriage is a necessity and the implementation of the marriage is natural because the woman wants to be married to a man who is equal and able to pay the mitsil dowry, while the guardian of the line 
does not exist, or do not want to marry her off, if the bride and groom do not want to postpone the marriage until there is a guardian of the lineage, then the judge will act as the guardian of marriage because there is a hadith whose contents cannot postpone this issue of marriage when it is natural (AKBAR, 2018).

\section{c. Wali Muhakkam}

Is a person who is appointed by the two prospective husbands and wife to act as a guardian in their contract. Wali Muhakkam, among others, is a respected person, a community figure, a respected person, a fiqh expert, can do justice, Islam, and of course must be a man.

d. Wali Maula

Is a guardian who marries his slaves. He was a master who was allowed to marry off female slaves under his control.

Wali mujbir is often defined as parents who can force their children to marry according to their parents' choice. Whereas in society it is known as the tradition of forced marriage which has a context of ikrah (coercion). The definition of ijbar itself cannot be equated with ikrah. If a person who loses his mind is like a madman, a woman who has not reached maturity, including women who are still girls, then it is permissible for a wali mujbir to do it. The basis of this ijbar is the hadith of the Prophet narrated by Bukhari which states that a widow has more right to determine her future husband than a girl. This shows that there are a classification and difference between girls and widows.

The power of a father as a guardian over this group is not the same as in the content of the hadith of the Prophet, where the widow has more rights over herself than her guardian. The definition of the term forced marriage is dualism in its meaning. The meaning of forced marriage can be equated with the definition of ijbar if it is done by a father or grandfather who forces a girl under his guardianship to be married to a man without the girl's permission on condition that (Kasthalani, 2016):

1. The groom must agree with the bride

2. The bridegroom- the man must pay the dowry in cash

3. There is no enmity between the bridegroom and the bride

4. There is no enmity between the married woman and the married guardian.

If these conditions are not fulfilled it can be said that forced marriage is the same as ikrah. The difference between the definitions of ijbar and ikrah lies in the force that occurs in the process of getting married. The idea of forced marriage is due to an understanding of what is known as the right of consent (Habibi, 2017). Many people understand the right of ijbar as the right to enforce a marriage by the guardian of the lineage, namely his father or grandfather (wali mujbir). The concept of ijbar raises the public's thought that a marriage may be forced based on the right of ijbar. 


\section{ANALYSIS OF FORCED MARRIAGE}

1. According to the Qur'an.

In general, the Koran does not clearly explain the problem of forced marriage (ijbar), but in the qur'an, several verses are mentioned which explain the problem solving of the family at the time of the Prophet as the answer that occurred during the period of that. This is under the principles of the Koran, which only explains general principles. The qur'an clearly states that a wali mujbir (father, grandfather, and so on) must not force his daughter to marry if the child does not agree with it or if the child only wants to marry a man of his choice, while a wali is reluctant or not. want to marry her off. In the al-Qur'an in Al-Baqarah verse 234, it is stated that let someone does not make it difficult for others to marry, if a wife has expired her iddah period then do not prevent her from remarrying her future husband in a good manner.

The word ijbar in translation into Indonesian means to impose or oblige on something, when parsed the word ijbar comes from the root word in arabic, jabara formed in wazan afala to become ajbara-yujbiru-ijbarun which means to impose and oblige to do something. The term ijbar means is the right to choose and determine who is a prospective husband for his daughter unilaterally. However, the right to ijbar is different from coercion (ikrah), which is often interpreted by the community as the argument for forcibly marrying off their children(Muttaqin \& Fadhilah, 2020).

Regarding this right to ijbar, jurisprudence experts differ in their attitude. According to Abu Hanifah, the consent of a woman or a widow must be in the marriage if they refuse, then the marriage contract cannot be carried out, even by the father. As for the basis used by Abu Hanifah in determining the existence of a girl's consent in marriage, including the case of al-Khansa ', namely the case at the time of the Prophet which stated that the Prophet rejected the marriage of a girl who was married to his father because the candidate did not approve. Meanwhile, according to Imam Malik, the consent of a girl in marriage is only a sunnah or as a compliment, without her consent, the marriage can be carried out by the guardian. Meanwhile, the consent of the legal widow is mandatory(Bakar, 2013, p. 82).

Furthermore, Imam Shafi'i allows the right of ijbar, meaning that a mujbir guardian can marry off his daughter without first asking permission from his daughter. As for the marriage of a widow, there must be express permission from the person concerned (Farah, 2008). Wali Mujbir is given the right to marry off their daughters to men who are considered good and come from good descent as well. Mujbir guardians are not automatically given mutual freedom in exercising their rights, some signs must be fulfilled for this ijbar right, including the necessity that there is no hatred between children and fathers, carried out based on providing insight, choices, possibilities, and alternatives.

It is better for the child, marrying the child to a compatible man (kufu), the prospective husband must be able to provide a dowry appropriately (mahar mitsil), 
there must be no hatred between the prospective wife and the prospective husband, the belief that the father's choice of man will not make him miserable after marriage. The guardian mujbir must pay attention to these signs(Armia, 2011). If these conditions are not fulfilled, a girl who has been married off without prior consent can ask the judge to destroy her marriage.

\section{Forced marriage according to positive law}

Based on Law Number 1 of 1974 concerning marriage, it states that marriage must be based on the consent of both parties to the prospective bride, without any coercion from any party. This article is emphasized in its explanation, that marriage has the intention that husband and wife can form a happy family, again by human rights. In addition to Law No.1 of 1974, the Constitution of the Republic of Indonesia also regulates human freedom in determining his choice, namely the existence of legal protections regarding the right to choose a life partner and to build a family in marriage, which is generally regulated in Chapter XA regarding Human Rights, article 28B of the 1945 Constitution which states, "Everyone has the right to form a family and continue their descendants through a legal marriage".

The existence of this provision in the constitution has shown that there are rights protected by the State for someone who wishes to form a family living in the sense that marriage is part of Human Rights which must be respected. Marriage issues are related to personal matters, so it is fitting for the constitution to regulate it because there are so many cases that occur in society relating to human rights violations in the field of marriage, especially acts of forced marriage(Bakar, 2013, p. 84).

Provisions regarding forced marriage are also regulated in Article 16 of the Universal Declaration of Human Rights, which states that "marriage can only be carried out with the free and full consent of the prospective bride and groom". The convention on the elimination of all forms of discrimination against women which has been ratified by Law No. 7 of 1984 states that women have the same right to enter marriage, either to choose a partner or husband freely.

Law of the Republic of Indonesia Number 39 of 1999 concerning Human Rights explains that humans are created to manage and maintain the universe and at the same time have inherent basic rights given by God since birth, namely Human Rights. Regarding the right to have a family and continue offspring, it is stated in Article 10 paragraphs (1) and (2), namely that every person has the right to form a family and continue their offspring through a legal marriage. (2) A legal marriage can only take place at the free will of the candidate. the husband and future wife concerned.

The occurrence of forced marriage makes the subordinate assessment of women starting when a woman is forced to marry an unknown person and has not been asked for prior consent, women are deemed incompetent in determining issues 
related to themselves so that women become an object, not a subject. Marriage carried out based on coercion will hurt the continuity of the marriage(Munir, Subekti, \& Rodafi, 2020).

The concept of human rights shows that every human being has legal protection of the right to freedom or independence to determine or decide his own choice. All decisions on a person's actions have nothing to do with the will of others, and the decisions are purely in the hands of the person who is doing it or is concerned. So it cannot be justified when someone forces another person to do any act that he does not want, in this context, namely forcing someone to marry. This contradicts the legal protection of the rights of women who are forced to marry as has been regulated by our country, namely Law Number 39 of 1999 concerning Human Rights.

\section{Comparative Analysis}

The occurrence of forced marriage is an implication of the power of ijbar rights possessed by a wali who in Islam a wali has the right to marry his daughter to a man of his choice without first asking for his child's consent because the guardian is considered to be the one who knows the best for his child so that the child's consent takes priority. The right of ijbar as a concept of guardian power is a condition of patriarchal values that make women unable to determine the best for themselves.

Whereas in the state law Indonesia does not recognize the right to consent, the consent and willingness of the two parties to marry are mandatory. The power of ijbar rights, forced marriage is also an imposition of the will and contrary to the concept of human rights which teaches that every human being has legal protection or the freedom to make his own choice.

Thus it can be analyzed that there is a shift in the value of the wali's ijbar right in Islam, the right to ijbar should be interpreted as the right to advise girls in choosing their life partners, not to control the power that causes the parents to force their children to marry, the value shifts that occur have been filled in. by state law that protects all citizens, especially women in determining their life partner, the existence of sincerity and the pleasure of both parties to marry which is regulated in the marriage law is an application of the non-recognition of the right of consent and protection for women in choosing a life partner.

Naturally, not only in this inquiry, but other issues will also occur. One of the informal also presents educational curricula with patriarchal preconceptions, as is the case with studies in pesantren education (Islamic boarding school). A key analysis of marriage, the book of uqud dul lujain, for example, is overwhelmingly portrayed and even marginalizes women. This book is sadly still in use in the circles of pesantren and has origins in the pesantren in the younger generations. If this research continues without anyone criticizing the pests, it may be a form of education, rather than a method of education. Studies that are "neutral" to the rights of women need to be 
investigated. Though Ijbar 's right strongly supports the rights of women in an Islamic approach

\section{CONCLUSION}

The authors conclude on the basis of this research that, honestly, the Koran does not justify forced marriage, let alone suggest it. Meanwhile, women have the same rights and roles as men due to constructive legislation. No one has a higher or greater right to select an option over others. All persons therefore have their rights secured, Ijbar 's theoretical idea was the rights and responsibilities of parents who have a sense of duty to direct their daughters according to Islam towards a successful marriage. In truth, however, there has been a change in understanding the meaning of the ijbar definition. This arises because of the public's perception of the ijbar definition, which is only positioned as a cultural practice or social demand. This mentality should be removed authoritarianly in this modern age because it is direct evidence of an act that violates Islamic law and positive law. Women, after all, have, from any angle, preserved their rights and utter dignity.

\section{REFERENCE:}

Ab Rashid, R., Mohamad, A., Musa, R., Rahman, S. B. A., Darus, S., Yunus, K., \& Shukri, K. (2018). Representation Of Islam In Social Media Discourse Produced By An Apostate. 2018 4th International Conference On Web Research (Icwr), 1-5. Ieee.

Akbar, A. (2018). Pendapat Yusuf Al-Qardhawi Tentang Hak Ijbar Wali Dalam Pernikahan Anak Gadis Dan Relevansinya Dengan Konteks Kekinian (Phd Thesis). Universitas Islam Negeri Sultan Syarif Kasim Riau.

Alqodsi, A. S., Bidin, S. N. B. S., Al-Shafi, M. M. O., \& Muda, T. F. M. T. (2020). Preventive Legal Procedures In Maintaining The Permanence Of The Islamic Marriage Contract: Malaysian Experience. International Journal Of Academic Research In Business And Social Sciences, 10(4), 408-420.

Armia, M. I. (2011). Kawin Paksa Dalam Perspektif Fiqh Islam Dan Gender (Phd Thesis). Universitas Islam Negeri Maulana Malik Ibrahim.

Bakar, A. (2013). Kawin Paksa (Problem Kewenangan Wali Dan Hak Perempuan Dalam Penentuan Jodoh). Al-Ihkam: Jurnal Hukum Dan Pranata Sosial, 5(1), 81-98.

Bell, L. G., \& Harsin, A. (2018). A Prospective Longitudinal Study Of Marriage From Midlife To Later Life. Couple And Family Psychology: Research And Practice, $7(1), 12$.

Faradila, R. H. (2019). Praktik Nikah Ijbar/Kawin Paksa Di Desa Barabali Kecamatan Batukliang Kabupaten Lombok Tengah (Persfektif Sosiologi Hukum) (Phd Thesis). Universitas Islam Negeri Mataram. 
Farah, A. (2008). Kawin Paksa Sebagai Alasan Perceraian (Studi Atas Putusan Pengadilan Agama Kendal No. o044/Pdt. G/2006/Pa. Kdl). Semarang: Iain Walisongo.

Gill, A. K., \& Hamed, T. (2016). Muslim Women And Forced Marriages In The Uk. Journal Of Muslim Minority Affairs, 36(4), 540-56o.

Habibi, I. (2017). Hak Ijbar Wali Di Desa Perupuk Kecamatan Lima Puluh Kab. Batubara Ditinjau Dari Uup No. 1 Tahun 1974 (Phd Thesis). Universitas Islam Negeri Sumatera Utara.

Hafidzi, A. (2019). Konsep Toleransi Dan Kematangan Agama Dalam Konflik Beragama Di Masyarakat Indonesia. Potret Pemikiran, 23(2), 51-61.

Hafidzi, A., \& Hayatunnisa, E. (2018). Kriteria Poligami Serta Dampaknya Melalui Pendekatan Alla Tuqsitu Fi Al-Yatama Dalam Kitab Fikih Islam Wa Adillatuhu. Syariah: Jurnal Hukum Dan Pemikiran, 17(1).

Hedi, F., Anshori, A. G., \& Harun, H. (2017). Legal Policy Of Interfaith Marriage In Indonesia. Hasanuddin Law Review, 3(3), 263-276.

Hori, M., \& Cipta, E. S. (2019). The Purpose Of Marriage In Islamic Philosophical Perspective. Journal Of Islamicate Studies, 2(1), 18-25.

Izzati, A. R. I. (2011). Kuasa Hak Ijbar Terhadap Anak Perempuan Perspektif Fiqh Dan Ham. Al-Mawarid, 11(2). Doi: 10.20885/Almawarid.Vol11.Iss2.Art7

Kasthalani, M. (2016). Hak Ijbar Wali Dalam Perspektifurf (Phd Thesis). Pascasarjana.

Lahaji, L., \& Ibrahim, S. (2019). Wawasan Fikih Indonesia: Studi Tentang Periwayatan Dan Penalaran Hukum Wali Nikah. Al-Ulum, 19(1), 1-26.

Mahbub, M. S. (2016). Upaya Pembatalan Pernikahan Atas Kesalahan Penetapan Wali Hakim Oleh Wali Nasab (Studi Kasus Pernikahan Dengan Akta 04/o4/I/2012 Di Kua Kecamatan Pabelan) (Phd Thesis). Iain Salatiga.

Mohd, A., \& Kadir, N. A. (2020). The Theory Of Compulsion (Ijbar) In Marriage Under Islamic Law: Incorporation Of The Hanafis View On Compulsory Consent In Marriage Under The Islamic Family Law (Federal Territories) Act 1984. International Conference On Law, Governance And Islamic Society (Icolgis 2019), 51-55. Atlantis Press.

Munir, M., Subekti, A., \& Rodafi, D. (2020). Kawin Paksa Dalam Perspektif Fiqh Islam Dan Gender. Jurnal Hikmatina, 2(3), 139-147.

Musa, K. F. (2017). Islamic Jurisprudence And Human Rights: At-Takhyîry Approach In Marriage Law. 1st International Conference Of Law And Justice-Good Governance And Human Rights In Muslim Countries: Experiences And Challenges (Iclj 2017). Atlantis Press.

Muslih, M. (2016). Al-Qur'an Dan Lahirnya Sains Teistik. Tsaqafah, 12(2), 257-28o.

Muttaqin, M. N., \& Fadhilah, N. (2020). Hak Ijbar Wali Tinjauan Maqashid Syari'ah Dan Antropologi Hukum Islam. De Jure: Jurnal Hukum Dan Syar'iah, 12(1). 
Sanford, N. (2017). Self And Society: Social Change And Individual Development. Transaction Publishers.

Syaifullah, A. (2016). Praktik Perpindahan Perwalian Dari Wali Nasab Kepada Wali Muhakkam Karena Walinya Adal (Studi Kasus Pernikahan Di Bawah Tangan Di Desa Penggalaman Kec. Martapura Barat). 